\title{
On the Accusative Weapon of the Poetic Image of London in William Blake's London against the Brutalities of English Realities
}

\author{
Jun Luo ${ }^{1 *}$, Guijun $\mathrm{Li}^{2}$ \\ ${ }^{1}$ School of Foreign Languages, Zhaotong University, Zhaotong, China \\ ${ }^{2}$ School of Foreign Languages, Dianxi Normal University of Science and Technology, Lincang, China \\ Email: *531678237@qq.com
}

How to cite this paper: Luo, J., \& Li, G. J. (2018). On the Accusative Weapon of the Poetic Image of London in William Blake's London against the Brutalities of English Realities. Advances in Literary Study, 6, 69-108.

https://doi.org/10.4236/als.2018.62008

Received: March 7, 2018

Accepted: April 27, 2018

Published: April 30, 2018

Copyright $\odot 2018$ by authors and Scientific Research Publishing Inc. This work is licensed under the Creative Commons Attribution International License (CC BY 4.0).

http://creativecommons.org/licenses/by/4.0/

\begin{abstract}
Although he has not been accepted as a famous English poet by the mainstream consciousness of his poetic production at his age, William Blake is now extensively regarded as one of the earliest and greatest figures who have pioneered the early romanticism in English literature. His typical poems have been discussed for a long time from various perspectives but the role of the image of London in his emblematic poem London has rarely been touched by scholars to make an exploration of the critical spirits of the poet. To attach an academic importance on the academic values in this respect, this essay will take London as an analytical sample to justify that the image of London in William Blake's London can be taken as an accusative weapon against the social brutalities of England in reference to the social reality of that repressive time based on a better analysis of the image of London in this poem from the perspective of reflectionism in terms of the social oppression, class repression, religious misconduct as much as liberal exploitation of English society as what can be seen in the poetic images of this poem.
\end{abstract}

\section{Keywords}

London Image, Accusative Weapon, Cruelties and Brutalities, William Blake, London

\section{The Textual Singularity of William Blake's London}

It seems to be a universal truth that the real superiority of a poetic text that has been epitomized with temporal and spatial canonicity tends to be denied upon its birth and admired after a rigid test of the poetic readers owing to its rebirth in 
the spiritual wonderlands of their minds. For the part of poet, William Blake is one of those poets who have been endowed with those poetic prophecies, for he has been neglected for a long time before he has been impartially thought of as one of the best lyrical poets in the last 500 years just as what has been put in the critical essay of Alexander Gilchrist that William Blake's poems have hardly known to those of his own generation not to speak of winning the popular flavor of the well-bred readers owing to his technical imperfection according to the specific academic views of Alexander Gilchrist, not until the present century it is do poetic scholars, critics and readers begin to understand him and his poems (Gilchrist, 1880). With respect to his poetic texts, London is one of those poems that have been typified with the critical transition from its textual unnoticed commonality to its he admiring singularity that have been catching the attentions of scholars and critics.

The reason for his late recognition in the field of poetic criticism is likely to be that he has produced a variety of the image of London that can be used to voice his indignant accusations of the power and authority that have been dominant in the entire epistemology and ideology of the social reality in a cruel and barbarian way in order to speak for the unbearable bitterness of the poor who have been caught in dire poverty in the form of leading a dog's life all the time. To this extent, the critical values of the poetic texts produced by William Blake lies in the ingenuous image of London he has portrayed in his poetic texts so as to show his relentlessness to make it known to all that the entire society he lives in has been thrown into the intolerable cruelty and brutality that have been deteriorating both the body and soul of the poor based on the valuable social conscience rooted in the fertile lands of his poetic world composed of social conscience, cultural conscience as well as moral conscience in the fashion of poetic criticism rather than poetic sycophantism.

Comparatively speaking, the most explicitness of those qualities in the image of London of his poetic texts has been manifested in this poem named in London whose shocking images and sounds in both explicit and implicit way has been believed to have been bearing the marks of the major chaos of almost all the social vices in $18^{\text {th }}$ century England in relation to the sound bitterness of the mass at that time. Therefore, the poem London that has been collected into the poetic collection under the title The Songs of Experience emerging at such a time that French Revolution has broke forth to astonish, irritate, and impel the whole world is one of the poems of William Blake that have been infused with or permeated into the textual texture the very kind of epochal typicality that is inclined to make it a microcosm of the social realities of England owing to the destruction of the wars at that historical moment as recorded in the following study of Stopford A. Brooke "Blake's The Songs of Innocence appeared in 1789, the year of its outburst. The Songs of Experience was engraved in 1794, when the Terror was dying. (Brooke, 1920)" It is in this way that London has carried the destructive signs of French Revolution and has much to do with the Reign of Terror, so 
it is best likely to suggest the strong indignation of the poet and the unspeakable bitterness of the poor exemplified in its subtle poetic images.

Grounded on the typicality and canonicity of image of London in the poetic text titled London as well as its critical responses to the social realities at that historical moment with an aim of taking into account the sound bitterness of the poor who have been living at the bottom of English society over French revolution and showing his concern for those who have been leading a poor and indecent life, this essay is inclined to devote most of its textual spaces to the elaborations of the strong protest William Blake has implied in the London images of this poem to abuse the cruel and brutal realities of English society at that time during French revolution owing to its destructive effects on the poor.

\section{The Critical Emphases on William Blake's London}

As far as London is concerned, both international and Chinese scholars have made their respective studies of from different respective according to their own understanding of this poem as manifested in the academic achievements they have made in their specific fields based on their specific academic interests and versatilities. To make it clear, it is necessary to give a general review of both international studies and Chinese studies of this poem in the following two folds as what to be done below in the order that has been put here.

Firstly, in accordance with the investigative findings of the literature review in this respect, most international scholars have paid much more of their attentions to the biographical and empirical explorations of William Blake as much as his other poetic texts while fewer of them have made a mention of this poem London in their studies. Among them, there are six representative studies that have been addressed to the true-to-life description of the city London in this poem according to the studies of Martin Price, Harold Bloom, Sayers Janet and Monin Nanette, Pramod K. Naya, Zengin Mevlüde as well as Almasalmeh Bassel respectively. To show their understanding of and comments on this poem, their representative studies in this respect will be given below one after another.

The first study in this respect is associated with the academic view proposed by Martin Price who has maintained that in London, this pattern of the externally imposed suppression that has takes the shape of the swaddling bands of the infant as much as the binding with barriers by the priests in black gowns or the internal self-imposed repression that has been seized with the armed fears of the virgin and the secret love of the rose has generally become a general condition whose profound implication meaning seems to be evident only to the visionary poet, for it is he alone who sees and hears everything that has been take for granted in the studies of other scholars (Price, 1969).

The second study in this regard ought be related to the studies of Harold Bloom who has claiming that William Blake has attached a very different and greater emphasis on the miserable images articulated and portrayed in the last four lines of the third stanza of this poem London in the honest expression of his 
irritated expression in the form of curses, tear as well as plague, for he has preferred to dig out the social realities implied in those lines and highlight the critical values of this poem in an objective way (Bloom, 1987). As a matter of fact, in the eyes of Harold Bloom, the curse of the nature that has been blighting the marriage coach and turning it into a pleasant hearse is connected with the venereal infection beginning with a sociological reading of rather than the close reading of the four poetic lines in the last stanza of the poem titled London in the light of the critical insights proposed in the critical theories and practices of new criticism. Nonetheless, while William Blake is talking about every marriage, he means that each rides in a hearse in the literal sense. In his terms, the plagues that have been voiced in this poem are the enormous ones that can be clearly traced back to the mainstream identification of the reason, the society, as well as the nature at that historical moment, and the greatest plague of them is the very jealousy of experience that has been epitomized in the dark in consistence with the secret love of the nature from the bottom of his heart.

The third study regarding this poem has much to do with the co-authored study of two international scholars named Sayers Janet and Monin Nanette respectively who have pointed it out that while reading William Blake's London, they aim at sensitizing poetic readers to have a good understanding of the burning plight of the most vulnerable citizens who live in London in the early $19^{\text {th }}$ century (Sayers \& Monin, 2012). According to them, their studies of this poem seem to address to the important issues related to the organizational theorization at the first sight by making use of the role that diabolical reading of this poem is likely to play in creating the mental flux of poetic readers in the textual flux of this poem by means of taking advantage of the visual and poetic symbolism to reach their research aim of contesting the entire language system of this poem just as what has been implied in the psychological effects that the institutional domination of the discursive rights has been having on the citizens of London but actually what they have been trying to tell their readers is that in reference to the textual configuration of William Blake, they have been taking the narrative voice of this poem as a wandering bard that has been placing the narrative intentions of this poem at the central region of London city and making it set in the unbelievable environmental deteriorations of this city in order to illuminate their academic readers the narrative art of William Blake as exemplified in this poem that the poet has been haunting his poetic readers by juxtaposing the substantial landscape of London with the decadent scene of English society in a metonymic way to the effect that the deteriorated similarity between them is best likely to tell the bitterness and worseness of the living conditions of London citizens as well as English society on account of the harmful impacts of French revolution.

The fourth study devoted to the explorations of this poem London is greatly concerned with the academic proposition of the scholar of this study Pramod K. Naya, who has made it possible to fall into two categories the role that the the- 
matic surveillance of this poem has been playing in the observations and witnesses of the decadence of London as explained below one after the other (Naya, 2014). As elaborated in this study, it has been made evident enough that the first category refers to the likelihood that the observation and data collection of the social dwellers of London are likely to be achieved in the occupational categorization of the social dwellers who have been exploited of their legal rights of living in this city on account of their own subversive or illegitimate activity that has been reluctantly chosen to make a living owing to the impersonal treatments they have been given in the social realities while the second category has much to do with the exploitative construction of the institutional spaces of various organizations in London that has been aimed to demonstrate a cartography of the spatial vulnerability that has turned out to be intersected with and the product of the chartered space in the city.

In this way can it is understandable that as what has been hinted in the spatial distribution of the textual spaces of this poem by the textual producer of this poetic text, the environmental and spiritual degradation of London is the inevitable effects and echoes of the spatial surveillance of the existential spaces of the social reality in both London and England, which is bound to worsen the homelessness of the poor who have been denied the rights to live in a city like London, a country like England and a society like English society. To this extent, the poor have been made outcasts of English society at that historical moment in the name of civility in barbarian fashion.

The fifth study devoted to the explorations of this poem London has been relevant to the contextual studies of the scholar named Zengin Mevlüde who has already given an interpretation of William Blake' London from the perspective of historicism, which has been firmly believed in the mind of this scholar to be likely to enable the poetic readers of this poem to historicize it by taking the texture of this poetic text as a product of historical development that can be regarded as a textual mirror to echo the miserable and wretched living conditions in reference to the cruel realities of English society at that age (Zengin, 2014). In view of the emphasis of this study, it ought to be noticed that what have been placed an importance on in this study is the poetic contextualization of the imagery implication of this poem on account of the conscience of the productive intention of William Blake to criticize the prevalent social realities of London and England, for it has been reflected in his poetic observation of English society that there is potential and inevitable danger for the heavy dependence on science and technology that have been dominant in the ideology and epistemology of English citizens and are neglecting the spiritual and humanistic values of man and limiting the spiritual liberties of them rather than liberating them in the form of scientific and technological rationalism just as what has been protested against in this poem in terms of the sins and vices of the government, the monarchy as well as the church that can be corresponded to the depiction of the chimney sweeper, soldier and harlot in this poem to the effect that the whole 
London and even England has been exposed to the absolute subjection the authority and power of the corrupted social system that is made up of those three major institutions as mentioned above. On the foundation of those analyses of the otherness of the poor, the scholar has reached the conclusion of this study that William Blake has been standing for the cornered, exploited, sterilized and impoverished voice of English society, and fighting against the social hegemony in this poem.

The sixth study devoted to the explorations of this poem London is a study of a scholar named Almasalmeh Bassel in his comparison he has made between W.B. Yeats's Sailing to Byzantium produced in 1927 and William Blake's London in 1794 from the perspective of deconstructionism in terms of the analysis of the verbal contradictions between them with regards to their meaning and structure by proposing and justifying that those two poems ought to be accepted as the typical examples of deconstructionism the former is modern but the latter romantic as it has been dealt with in the conclusion of this study that those two poem can be compared with each other with the theoretical illumination from the deconstructive approach after an ingenuous scrutiny of them, for on the one hand, the theoretical evidence manifested in deconstruction is likely to uncover the instability of the language and meaning of this poem and on the other hand, the textual samples of this poem to reveal the clashes between the signifiers and the signified of this poem (Almasalmeh, 2014).

To be brief, most international scholars have either made a concrete mention of or made a systematic study of William Blake and his other poetic texts from the point of view of his biographical exploration in combination with the correspondent poetic texts of William Blake which they have taken interest in, his empirical reflection in the process of his poetic production as well as the burning concern they have believed William Blake has been likely to show for the spirituality or mentality of the poor as well as the immorality of the mainstream consciousness of the whole society. Few of them have put the textual codes of this poem London into the impersonality of the social realities of England at that time to reveal the social vices of English society in $19^{\text {th }}$ century but fewest of them have devoted their studies to the elaboration of the correlation between the depictions of the city London in William Blake's poem London and the social realities echoed in this poem, let alone the role this correlation is likely to play in prevention the social vices and the promotion of the social virtues of the society at that time.

Secondly, what ought to be admitted in this essay is that in comparison with the attentions international scholars have paid to this poem London, more Chinese scholars have also placed an importance on the studies of it from different perspectives as summarized below in accordance with the analytical approaches of these scholars who have devoted their critical spaces to this poem in the process of their construction of the textual spaces of their studies in their specific critical practices. According to the systematic comparison of one of the academ- 
ic resource with another based on the acquisition, categorization, integration as well as reorganization of the academic achievements of Chinese scholars with respect to the textual analyses of this poem London and contrasts it with other poetic text, the epitomized studies of Chinese scholars in this respect are likely to fall into the seven groups as summarized below in terms of the imagery analyses regarding the poetic images of this poem based on the theoretical insights of imagism, the narrative analyses concerning the spatial construction of this poem, the comparative analyses between the poem London produced by William Blake and the poem in the same title London written by William Wordsworth, the stylistic analyses of this poem in three folds respectively, the thematic analyses of this poem as well as the rhythmic analyses of this poem one after another.

The first group of those studies made by Chinese scholars (Zeng Fangrong, et al.) has been seen in the explorations of the images in this poem from different analytical dimensions and composed of five minor studies in this regard but from different points of departures just as what to be clarified below one by one.

The first minor study in this respect has been combined with the imagery exploration of this poem in the studies of a Chinese scholar named Zeng Fangrong who has hold that William Blake is a poet living in the later half of $18^{\text {th }}$ century and the beginning of $19^{\text {th }}$ century who has been proved to witness the successive influence of industrial revolution as well as French revolution on the miserable living conditions of English citizens who have been living in that time at the risk of suffering from unspeakable bitterness on account of the harsh realities of English society at that historical moment. In line with this study, the scholar has dealt with the academic insinuation of the so-called social morality and civility of English society at that time by giving a vivid account of the poetic images in the poetic texts of William Blake without being reduced to the imagery exploration of this poem London. In a sense, this minor study has been holding more academic attention of poetic scholars who have been interested in the poetic images of the poetic texts of William Blake in more than one fold (Zeng, 2005).

The second minor study in this respect is greatly concerned with the darkness of the dehumanized shadow of London has been discussed in the co-authored academic studies of the two Chinese scholars Wang Xueqiang and Zhao Zhigang who have been linking the specific poetic reality of London with social reality of England at that time in the remarkable comparison between the poetic representation of London and the factual presentation to it based on their sociological interpretation of this poem London (Wang \& Zhao, 2008). It is in this way that they have been deeply impressed that the gloomy and filthy image of London as what has been manifested in this poem London is, to a greater extent, the reliable insinuation or representation of the harsh reality of English society at that time, for in their minds London is a microcosm of England while England a macrocosm of London in more than one respect due to the panoramic similarity between the oneness of London and the wholeness of England in the light of the 
harshness of social reality. According to the exemplary justification of those two scholars in their critical insights, the cries of the infants and the chimney sweepers, the sighs of the soldiers as well as the forces of the unspeakable hatred at the bottom of the poor and the weak who have been treated as the underdogs or unlucky dogs of the society just as what has been depicted in this poem have been dug out and used as the textual evidences or analytical samples for the justification of their academic proposition. In other words, they have been holding that William Blake has already made full use of his rich imagination to reflect and criticize the brutal realities and the social vices of English society at his age in a ruthless way as what has been actualized in this poem with the textual factuality rather than the textual fiction of this poem taken into account.

The third minor study in this respect is composed of two studies. The first one has something to do with the studies of a scholar named Zhan Changjuan who has devoted most of the textual spaces of her studies to the two poetic collection produced by William Blake, namely, Songs of Innocence and The Songs of EXperience, for she has placed a special emphasis on them respectively (Zhan, 2013). By and large, she has been giving an interpretation of the stylistic features and making correspondent comments on William Blake's poetic texts just as what has been elaborated in his most typical poem London while making an exploration of the stylistic traits and thematic properties of this poetic Songs of Innocence where the poem London has been collected. According to Zhan, she has placed a great importance on the studies of London with regards to the poetic techniques demonstrated in the textual production of this poem in term with the poetic image of this poem as well as the three encounters portrayed in this poetic text apart from the symbolic capitalization, the musical configuration of the poetic structure of this poem in regard to its rhymes and rhythms in reference to the acoustic illumination of a train of musical thoughts, the ingenuous diction and the repetitive words that have been likely to be conducive for the manifestation of the theme of this poem. Based on the analyses made above, she has finally reached a conclusion that William Blake has been having an overall impact on the adequate presentation to the horror and injustice of the social realities of England in his time as has been exemplified in the depiction of the poetic image of this poem London.

The second one has much to do with the spatial studies of William Blake's poetry in the studies of three Chinese scholars like An Ran, Zhao Shuying and Liu Wenyi who have made a spatial analysis of William Blake's poetic texts by indicating that as one of the most important poets in the history of English poetry, William Blake has infused into his poetry rich imagination that makes a series of leaping images and spatial grids that have brought about the strong effects of visualization with the theoretical enlightenment of narrative theories in support of the their elaborations to the spatial narration of poetic texts and the feasibility of making an exploration of the spatial narration in the poetic narrative texts of William Blake before they draw a conclusion that there are a variety of 
spatial grids in the William Blake's poems, for those spatial grids have been likely to give a vivid picture of the visual experience and aesthetic perception, which has been believed to be likely to bring the poetic readers of William Blake into a visual kingdom as illuminated by his poetic mysticism (An, Zhao, \& Liu, 2014).

The fourth minor study in this respect begins with the philosophical meditation on the definition, the purpose as much as the function of image in the academic studies of a Chinese scholar named Wang Lin before realizing that it has been used to indicate the existential presence of all the objective matters for the aim of the articulation or release of the subjective sentiments of human beings as their responses to those objective existences (Wang, 2009). With this thought kept in mind, Wang begins to think about the truth that what a poet is in a position to do in his poetic production is to enrich the visual significance and implication of the poem he is producing and is going to produce so as to make his own poetic views articulated and the poetic value of his poetic text realized. What makes Wang disappointed much at the visual manifestation of the poetic image in the poetic texts of most poets is that not every poet is able to give an adequate or a perfect presentation to or manifestation of the poetic image of the poetic texts he is producing and is going to produce except for William Blake, for in the mind of Wang, William Blake is best at enriching and deepening the visual values and implications of his poem. To elaborate this thought, Wang has taken London as an analytical sample to show how he has been making the best of poetic image and make an analysis of the historical and individual reasons why he has been best at doing so in the visualized construction of the visual world of his poetic world in the interesting process of his poetic production.

The fourth minor study in this respect refers to the studies made of by Wang Yingying, a Chinese scholar who has devoted much of the textual spaces to the exploration of Wang William Blake's poem titled London in one of her critical essays under the title of An Exploration of William Blake's London with an aim of finding out his imagery configuration and acoustic or rhythmic combination in the visual and musical construction of the poetic image respectively in this poetic text by means of giving an elaboration on the crucial role that poetic images and rhythms have been playing in highlighting the poetic theme, beautifying the poetic form and sound, enriching the poetic implication of this poem and achieving the harmonious unification of the poetic form in terms both the images and rhythms with the poetic implication of this poem in an aesthetic and organic way grounded on her original understanding of the aesthetic effects that those visual and musical components of a poetic text are likely to have on the promotion of the beauty of the poetic image of this poem (Wang, 2013).

In short, although those studies as reviewed above have been focusing on the poetic image of this poem, their elaborations have been reduced to the aesthetic and thematic effects of the poetic image of this poem. What they haven't been aware of in their textual analyses is that the poetic image of this poem is also likely to be regarded as a critical approach to the social vices of English society 
with respect to its cruelties and brutalities at the age of William Blake.

The second group of those studies made by Chinese scholars have centered on the narrative analyses that can be made of this poem London in the narrative studies of Yue Hui who has been showing a strong critical interest in making a narrative analysis of this poem for the aim of making an exploration of the spatial form in this poem in regard to its narrative space (Yue, 2013). In the eyes of Yue, poem is traditionally narrative, for the overall configuration and narrative progression of the poem can be made available from the linear extension of its temporal passage with the correlation between the spatial and temporal, structures, designs and constructions taken into account. According to this scholar, William Blake is both poet and painter, so his poem London has much to do with painting and ought to be discussed and elaborated spatially from two folds respectively: one is thematic space and the other static space. In the successive elaboration of the spatial proposition of this study, Yue holds that the narrative space in this poem stands for not only the spatial shift of the narrative places in this poetic text but also the fulfillment of both structural adjustments of this poem and emotional release or catharsis of the poet. On the basis of those analyses, Yue has reached a conclusion in this study that William Blake's poems like London can be regarded as an ingenuous combination of poetic arts and painting arts from the perspective of poetic aestheticism.

The third group of those studies made by Chinese scholars ought to be viewed as comparative studies that have been made of by Chinese scholars and the analytical details will be given in the following five respects in line with the analytical preferences and comparative interests of those scholars who have been dedicating their studies to the comparative analyses between William Blake's London and William Wordsworth's London in more than one dimension right after taking into a careful consideration the thematic, rhythmic, rhetorical and stylish similarity and differences between those two poems that have been under the same title London in a coincidental fashion.

The first comparative analysis that have been carefully made in details between William Blake's London and William Wordsworth's London seems to have been clarified in the critical findings of Guo Xiaoqing who have been paying enough attention to the contextual comparison between those two poems in respect of the difference of epochal background and poetic schools of them between them respectively and the thematic similarity between them in terms of their true-to-life depiction of the lives of both the middle classes and the upper classes of English citizens in the capital of England in the close of $18^{\text {th }}$ century and the outset of $19^{\text {th }}$ century (Guo, 2014). However, in accordance with the contextual comparison of this scholar, the poetic context of them has been differing a lot from each other in that the poetic context of the former has suggested that London is hellish, ugly and horrible while that of the latter has been turning it into a poetic and pictorial wonderland and giving the poetic lovers, poetic readers, poetic scholars as well as poetic critics an ingenuous impression. 
In the scrupulous comparison and observation of this scholar, it has been made evident enough so that the contextual comparison between those two poems in this valuable study has been concentrated on the contrast between them in regard to the poetic gist, the poetic rhyme as well as the poetic rhetorical articulation of those two poems in details in a respective fashion for the aim of making an analysis of the contextual differences between them and dating back to the right reasons for the sharp differences between them concerning the different poetic images of those two poems under the same title London on the way to the revelation of the social essence of London in the hands of the bourgeoisie of England at that time by means of giving their poetic lovers, poetic readers, poetic scholars as well as poetic critics a profound impression in a different way that in spite of the remarkable difference from each other on the poetic image of those two poems, London has turned out to be the paradise of the rich and the ruling classes of London or even England and the prison or the hell of the poor and the ruled classes right over there according to the comparative illumination the scholar of this study has obtained just as what has been explicitly demonstrated and exemplified in the contextual comparison between them.

The second illuminating comparative analysis between William Blake's London produced in 1794 and William Wordsworth's London written in 1802 has been made of in the comparative studies of Pan Yuwen, a Chinese scholar who have been taking academic interest in the comparative reading of those two poems respectively and the comparative reading of them simultaneously in order to reach the academic aim of giving an essential presentation to the genuine social vices hidden behind the superficial phenomenon of the capitalist prosperity in England over French revolution and industrial revolution regardless of the profound truth of the social realities of England at that historical moment, and the gigantic consistence between the productive background and intention of those two poems in addition to the respective styles of those two poets in their respective poetic production in relation to the textual configuration and language properties of this poem (Pan, 2001).

The third comparative analysis between William Blake's London and William Wordsworth's London is primarily embodied in the studies of Qiu Leying, a Chinese scholar who has devoted the textual space of one of his critical essays to the comparative exploration of the similarities and differences between those two poems in terms of poetic structure, language styles, the tenses as well as the applications of the subjects to exemplify the different productive style of those two poets apart from the ugly realities that have been hidden behind the prosperity of the capitalist society in England at that time grounded on the insights the scholar of this study has obtained from the respective reading of those two poems (Qiu, 2003). Based on those insights, Qiu has reached a reasonable conclusion in this study that although there are a lot of differences in the textual structure and language property of those two poems, the similarities can be expounded in the same epochal background of those two poem that has been cha- 
racterized with the universal existence of the disasters English people have been suffering from in their lives, which has been used to reveal the ugly realities of capitalist society by pointing it out that this disasters have been brought about by the capitalist society of England grounded on conspicuous concealment of the very social vices of the capitalist society in the superficial prosperity of English capitalism by the bourgeoisie.

The fourth comparative analysis between William Blake's London and William Wordsworth's London has much to do with the academic curiosity of a Chinese scholar named Wang Shalie about the poetic differences that have been likely to exist in two famous English romantic poets who have produced their poetic text under the same title London in spite of their thematic similarity to each other in that they have already articulated their respective dissatisfactions with the social realities of their ages as critical responses to the social darkness they have witnesses and shown their profound sympathies for English citizens at that time in reference to the authentic situations of the social realities of London based on a detailed comparison that have been made in this study to place a greater importance on the differences between those two poems with regards to their respective styles (Wang, 1992).

The fifth comparative analysis between William Blake's London and William Wordsworth's London comes from the poetic studies of a Chinese scholar Chen Xiaoling who has kept in her mind her confusion about the social essence of London without knowing whether it is the heaven or the hell of English citizens who live at that time, for in her mind the two poets have given two completely different interpretations of the same city London in their respective poetic masterpieces, which can be seen in her specific comparison that the former has been making his best to dig out all the ugliness entailed in the pictorial depiction of the city London while the latter racking his brains to give a presentation to the unmatchable beauty of the same city London (Chen, 2004). According to this scholar, what she is trying to achieve in her study is to find out firstly the thematic differences between those two poems including the differences between two poems regarding their respective poetic gist, the difference between two poem concerning the objects they have chosen to articulate their different lyrical sentiments, the differences between two poems with respect to the poetic contexts of those two poems, the differences between two poems in regard to the stanza forms of those two poems, as well as the differences between two poems with regards to the language properties, dictions as well as rhetorical devices between those two poems, and secondly the original reasons for those social differences in terms of their different outlooks on life, world and value that have been greatly associated with their different experiences. Just as what has been manifested in the conclusion of this study, Chen draws a conclusion that the former poet has shaken off the dogmatic bonds and chains of classicism that has been popular in the poetic production of $18^{\text {th }}$ century, rewritten the lives and dreams in fresh ballads and unrestrained blank verses, given a vivid presentation 
to the binary opposition between the kindness and wickedness rooted in the souls of human beings in the form of both surprising simplicity and profundity by means of taking his poem as a tool to show his internal sympathy for the poverty of the citizens of England, and voice his discontent with the social realities and fulfill his aim of revealing the social sins of England as exemplified in London, and pioneered the new poetic tradition of romanticism, while the latter poet lives in the golden period of romanticism, which stands for a poetic revolution whether in form or content, for the poet has been expected to make use of the simple and vivid vernacularism of the folks to express the sentiments of average citizens in natural ways and forms that can be felt in the uniqueness of his poetic lines.

The third group of those studies made by Chinese scholars has been seen in a study that has been made of by a Chinese scholar named Wu You as exemplified in the stylistic analyses of William Blake's poem titled London, one of the poems that have been paid most attentions to among the poems collected in his famous poetic collection under the title of Songs of Experience by making use of the theoretical insights of modern stylistics in terms of the variation of the superficial structure of this poem, the variation of the profound structure of this poem as well as the over-regularization of the poetic structure of this poem for the aim of having a better understanding of this poem and improving the appreciative competence of English poetry (Wu, 2015).

The fourth group of those studies made by Chinese scholars ought to be felt in the studies of Sun Ailing, who has made a study of the poetic them of this poem London in terms of the thoughts of anti-rationalism and pro-emotionalism in the poetic production of William Blake who has been remembered as the pioneer of romanticism in pre-romanticist period and characterized with his poetic originality regarding the poetic forms and skills, for in the eyes of Sun, William Blake has turned a deaf ear to the classicist English poetic tradition typified in the poetic texts of Alexander Pope, and begun to acquire the poetic inspiration from the poetic tradition over Elizabethan period and the lyrical poems in $16^{\text {th }}$ century, and obtained poetic literacy from the examples that have been set in the poetic lines of pastoral poems of $18^{\text {th }}$ century poets (Sun, 1999). In the major findings of this study, Sun has pointed out in a conclusive way that William Blake's poem has been remarkably and attractively characterized with the profound democratic thoughts on account of the simplicity of his poetic diction, the rich imagination of his poem, the bright image of his poetic text as well as the sincerity of the poetic emotions and sentiments voiced in his poems just as what has been felt in his London.

The fifth group of those studies made by Chinese scholars in this regard can be exemplified in the stylistic studies of Li Zixin and Ma Yangyang who have made a metrical and rhythmic analysis of London that has been widely accepted as one of the famous romanticist poem produced by William Blake in their co-authored essay titled A Rhythmic Analysis of William Blake's London that 
aims to give a better elaboration to the thematic implications and emotions of this poem from the perspective of stylistics in the light of the perfect combination of phonetic implication with semantic implication, the visual and acoustic stimulation brought by alliteration, the highlight of the emotions of the poet through the intensification of the rhythms and meters of the poem just as what they have claimed in their studies that the application of the evident rhythmic and metrical skills in the poetic production of William Blake has enriched the stylistic implication of this poem and has highlighted the thematic profundity of this poem in the association of the poetic content of this poem with its poetic emotion in order to place a great emphasis on the bitterness of English citizens by showing his deep concern and sympathy for them and holding his critical attitude towards the cruel realities of English society at that historical moment based on his strong perception of the roles that the rhythms and meters have been playing in the articulation and manifestation of the theme of this poetic text by means of making use of the rhythmic and metrical variations to give a full presentation to the implication of poetic text and purified its poetic soul ( $\mathrm{Li}$, \& Ma, 2017).

The sixth group of those studies made by Chinese scholars in this respect is relevant to the studies of another Chinese scholar Li Haiyun who has aimed to give a new interpretation of the imagination of this poem London in 2007, which has turned out to have stirred a great sensation among the poetic readers grounded on the immediate stimulation of their imagination and emotion in their reading practices of poetic texts like London ( $\mathrm{Li}, 2007$ ). According to $\mathrm{Li}$, it has been suggested in this study that William Blake has given a vivid description of London in his poem London by having a good understanding of the subtle imagination of this poem from the perspective of an objective observer but the scholar has attached a greater emphasis on the poetic intention of William Blake by claiming that the poet has permeated into each line of London his miserable sentiments for the miserable and strong resentment against the social vices, for his flamed emotions has been instilled in almost every corner of this poem in an abundant way on account of his strong objection to the poetic rationalism in $18^{\text {th }}$ century and his pursuit of personal liberation in poetic production by means of attaching an great importance on the poetic imagination rather than choosing to follow the theoretical proposition of natural mimesis that has been proposed by neo-classicists and made popular in that time on the basis of giving an account of not only the social reality in the future but also that at present, which makes his poem filled with systematic originality from the poetic content to the poetic form of his poems as typified in the thematic sharpness and formal uniqueness in his poems like London. As has been concluded in the major findings of the studies of those two scholar, they have been holding that the poetic imagination seems to be the source of the poetic production of William Blake, for he has been familiarizing with the flexible and subtle application of all poetic skills by implanting into his poem his emotions, perceptions and thoughts to help his poetic 
readers, poetic scholars and poetic critics to have a good perception of the artistic charms of his poem decorated with nothing but simplicity and have a good understanding of the ruthless revelation and criticism of the darkness of the social realities as dealt with widely in his empirical world.

The seventh group of those studies made by Chinese scholars has been epitomized in the theoretical exploration of Xie Nan who has made a very profound analysis of the organizational function of literary field by taking William Blake's London as a textual example grounded on her introduction of the theoretical implication of literary field from the social theories of Pierre Bourdieu and her textual analyses related to the application of the theoretical insights of literary field into the analytical practices of this poem London in two folds including the organizational function of literary fields by gathering similar images and composing integrated internal structures to get close to her final conclusion that William Blake's London has stood for all the fascinating literary elements and artistic ingenuities as stated in the theoretical elaboration of literary field on account of the subtle combination of the visual images with the acoustic rhythms of this poem (Xie, 2010).

To sum up, Chinese scholars have made a series of academic breakthroughs in their studies of William Blake and his poetic texts in various respects as analyzed above but they have seldom made it clear that the image of London in this poem has been regarded as a powerful weapon for the poet to voice his indignant accusation of the sins and vices of English society at that moment.

Thirdly, it can be inferred from the reviews of the academic achievements of both international and Chinese scholars that they have discussed much about London from many different perspectives but few touched whether the image of London in this poem can be treated as a powerful weapon the poet has been taking to accuse English society of its sins and vices. Therefore, this has been left alone as one of the important academic limitation in the studies of this field.

In view of this academic in-adequateness, this essay will try to think about the feasibility of the academic proposition mentioned above in reference to the social reality of that time after a careful analysis of the poetic image of this poetic text in association with the theoretical implication of reflectionism by taking the poetic image in this poem as a reflection of social oppression, class repression, religious misconduct as much as liberal exploitation of English society through the poetic images of this poem.

\section{Reflectionism as an Analytical Device of William Blake's London}

\subsection{Poetic Image as a Reflection of Social Vices}

In the field of Marxist criticism, the critical exploration of the correlation between the world and the text has been frequently proposed and expounded in the theoretical development and textual analyses of literary studies. One of those theoretical insights has been termed as reflectionism that has been believed to be 
a remarkable tendency in the reviews and explorations for the aim of achieving theoretical breakthroughs by taking it as an important way to argue with formalism over its linguistic and structural confinements of the theoretical studies and textual analyses in the internal structure of the textual composition with regard to not only the language structure but also the textual structure of a text, and not only structure of the language and text of novels but also of poems owing to the claim that author is death for the aim of avoiding the so-called affective fallacy and intentional fallacy.

In line with the theoretical proposition of reflectionism, the studies of literary texts ought to be shifted from previous internal studies to the present external studies by taking into account the external studies of both the theoretical generalizations and the textual interpretations in the specific practices of both novels and poems just as what Georg Lukács has put forward in his studies the notion that the appreciation, analyses, interpretations as well as explorations of the texts whether novels or poems are greatly concerned with the acquiring decodements of the correlation between texts and world from the textual components of literary texts like novels and poems, for in the studies of Georg Lukács, the textual codes carried in the structural collaboration of literary texts are the reflective messages encoded in the process of textual production. In his terms, all possible appreciation and interpretation of literary texts are also nothing but the reflections of the external world that has been echoed in the textual world of those literary texts in the mind map of the writers.

If there should be any difference between them, what has happened in the real world ought to be called social reality while what has been articulated in an artistic and subtle way in the textual world textual reality. In this sense, the correlation between the world and the text can be translated into that between the social reality and textual reality according to the means that have been tried to manifest it with respect to either the social virtues or social vices in the form of either literary content or literary form. Based on this thought, it will be feasible to deal with the exploration of treating poetic image as an important way to reflect what has been entailed in pictorial or visual way, for what has been manifested and articulated in poetic image can be turned into visible poetic pictures that can give the readers a sense of authenticity as what it is likely to give the audiences of the actual pictures they have been appreciating in artificial production in the form of painting or natural exposition through the reliable observation of nature in person.

What needs to be emphasized on herein is that the social reality in actual world is reflected by the textual reality of textual world neither mechanically nor subjectively, let alone correspondingly and equivalently, for it has been indicated in the studies of Georg Lukács regarding the aesthetic reflectionism that literary texts is the dialectical wholeness of thinking of the textual reality exemplified in literary texts as not only a reflection of the social reality of the actual world but also a transcendence of it owing to the interaction between the subjects and ob- 
jects of them in a subjective and active way.

In this sense, the artistic fulfillment of the aesthetic values of the social reality in actual world in the textual reality of the textual world of literary texts relies much on both the artistic design of the literary texts but also the positive participations of the readers. It is true of both novels and poems in more than one respect as shown in the theoretical elaborations (Zhu, 2006).

\subsection{Poetic Image as a Reflection of Class Struggle}

Based on the instinctive conscience of a critic like Georg Lukács, the interpretation of literary texts ought to be focused on the critical awareness of the critics with regards to the notion that literary texts ought to be accepted as the artistic representation of the mode of social production through poetic production in a given society where the class consciousness of the proletariat and the bourgeoisie has been located just as what has been dealt with in the interpretation of the understanding and function of class consciousness according to what has been manifested in elaborations of the Friedrich Engels that "nothing happens without a conscious purpose or an intended aim".

In some measures, this has reminded the critics of the voices articulated in the textual construction of the writer on behalf of the underdogs in the forms of both the textual mutability and textual immutability of the literary texts they have been reading in their critical practices, the class consciousness manifested in literary texts has brought about the social feed backs to the historical realities of a given society own to the fact that what it has been on behalf of is the combination of the social production which has been filled with the productive interactions between the bourgeoisie and the proletariat of a society just as what has been greatly impressed in the textual world in the light of the thematic construction of the literary production in the producing practices of the writers. For the part of the former, the textual production is an artistic articulation of the thoughts and sentiments of the ruling class and the ruled class of a given society with the remarkable signs of textual indignation. In the case of the latter, the manifestation of those thoughts has been seen to be finished in the form of textual production rather than the indignant demonstrations or strikes on the squares or streets that have been frequently peopled with a large population for fear of governmental repression.

With those two forms taken into account, the acoustic articulation of the voices of lower classes ought to be best completed in the image of poetic texts in accordance with the realistic tradition of critical realism as proposed in the claim of Georg Lukács that “... what Lukács is calling for, then, is essentially for the modern age to move forward into the nineteenth century. We need a return to the great tradition of critical realism ... (Eagleton, 2002)" in line with the illuminative summary of Tarry Eagleton.

The reason for this critical realism is likely to have much to do with what has been evident in the explanations of Karl Marx as quoted below “... Men's reflec- 
tion of social life and consequently his scientific analysis of those forms, take a course directly opposite to that of their actual historical development (Lukács, 1971)" as referred to in the theoretical interpretation of Georg Lukács.

Grounded on this epistemological enlightenment, it is likely to be realized that the image of poetic texts can be viewed as a possible approach to the critical realism, for it has actually been believed to be a textual carrier of a variety of both harmless and harmful thoughts caused by a series of social realities as witnessed in the ingenuous world of poetic text in the suggestions of the possible struggle between the ruling class and the ruled class of the society a poetic text has been set in.

\subsection{Poetic Image as a Reflection of Religious Ugliness}

In accordance with the rule that the social form of a society is determined by its social existence just as the consciousness by the matter in philosophical elaboration to the correlation between the social existence and social consciousness of a society from the perspective of historical materialism and the superstructure by economic base in the dialectic interpretation of the economic laws in the economic explorations, it ought to be made clear that literature is to a great extent of the correspondent echoes or responses to the realities of a society in the form of something that has been attached to the superstructure of a society, which has been likely to be exemplified in its religious progression or regression.

In this way, it can also be inferred that the religious phenomenon of a society is to a great extent the reflection of its religious realities although it ought to be admitted that those reflective correspondences are neither likely to be the symmetrical one-to-one correspondences as indicated in the digraph of the functions in mathematics nor are they likely to be the dynamic or static equivalences between the lexical equivalences as dealt with the correspondent equivalents between two languages in translation studies that have been put forward by Eugene Nida.

In abstract sense, this is in consistence with the artistic thoughts of Georg Lukács who has come up with the artistic thought that the basic materialism of each artist have evidently been manifested in the clear reflection or representation of the right description of the priorities and motivations that is likely to make the consciousness of the characters come into being, which has been articulated so clearly by Raman Selden in his critical interpretation of it (Selden, 2003).

Of course, the acquisition of either the superficial phenomenon or the authentic phenomenon rests much on the variety of the religious and social consciousness and social perception of the readers who have been devoted to the profound and overall perception of literary texts, for their epistemological progression or regression has much to do with the possibility for them to get close to the superficial phenomenon of the society or get away from the authentic phenomenon of it. An example in this respect can be found in the exemplary elaboration of the 
surprising religious degradation in the poetic masterpieces of Geoffrey Chaucer titled The Canterbury Tales in the revelation of the religious corruption in the social realities of middle ages.

In other words, just as other literary forms or genres are likely to be considered as a reflection of the consciousness that has been implied in both the superficial phenomenon and the authentic phenomenon rooted in the realities of a society in accordance with the understandability of the readers of that literary text, the poetic image indicated in this poem London is also likely to be viewed as a poetic carrier of the factual messages that have much to do with the social realities of England at that time with regards to the religious ugliness articulated in the religious scandals, religious corruptions as well as religious decadence of a society whose social ideology has been greatly based on the religious beliefs, practices as well as pursuits of its believers who have also been regarded as the citizens of that society owing to their ontological existences there.

\subsection{Poetic Image as a Reflection of Sexual Repression}

In responses to what has been elaborated above in brief, it is necessary to deal with an exploratory continuation of similar relationship between the literary characterization and the religious beliefs that have been believed to an indispensable way for the readers to get close to their fulfillment of spiritual redemption, liberation or salvation as what to be expounded below.

In the case of the correlation between literature and the abundant epistemological enlightenments of the characters of literary texts, what ought to be accepted is that the studies of literature is in some measures those of the instinctive personalities of human beings who have been typically exemplified in the characterization of the textual production in the epistemological construction of the character of a certain literary text while those studies will inevitably be imprinted on the indispensable traces of the social realities that have been preventing the harmonious development of humanities or at less limiting the full fulfillment of humanities owing to the very beliefs that have been manipulated by the dominant epistemology or ideology with the help of the religious persuasions offered by religious asceticism.

This is the same with the reflective thoughts dug out from various literary phenomenon that all great arts by Raman Selden is likely to give a picture of the world that has been serving as the origin of various social realities in the form of either social virtues or social vices. In this world, all the conflicts reflected in those social realities in terms of the binary oppositions between the superficial phenomenon and the authentic phenomenon, between the undiscovered particularity and generality as well as between intuition and abstraction have been solved in the process of either the individual distortion or perfection on account of the epistemological domination or the ideological manipulation of the dominant thoughts as implied in the pictured image of the social reality.

In this case, the images that have been designed and depicted in a literary have 
to some extent echoed the brainwash or ideological superintendence of the dominant thought just as what has been equivalently portrayed in the correspondent realities of that society. This point taken into account, it might be made evident enough that the poetic image of poetic text is also likely to be treated as a mirror to give a brief account of the panoramas of a given society just as what has been argued in The Meaning of Contemporary Realism of Georg Lukács that "modern writers should do more than merely reflect the despair and ennui of late bourgeois society; they should try to take up a critical perspective on this futility, revealing positive possibilities beyond it" in accordance with the theoretical retrospection of Tarry Eagleton.

This pointed implanted into the textual analysis of this poem London, what is likely to be reasonable is that it is possible to tell the religious repression of humanities in the name of the manipulative values and motivations that have been hidden from the implicit religious values of the religious asceticism that has been firmly upheld by the Puritans who have been lost in their pursuits of their religious values in a blind and faithful way without knowing that they have been inclined to be manipulated by the politicians in a religious way. The critical aim of reflecting this religious hegemony is to raise the attentions that can be paid to the vices of this religious repression and epistemological or ideological exploitation of English citizens at that time, the efforts that ought to be made to subvert it and the necessity to smash the spiritual shackles of English citizens for the aim of promoting or quickening the final regression of humanities of those citizens at that historical moment on the basis of their epistemological development with respect to the overall fulfillment of their physical needs in various forms by the lights that have been thrown on them and have been illuminated by the critical spirits implied in the textual construction of this poem in a subtle way that can not be perceived by ordinary readers who are not good at making the best of their imagination and association in the process of their poetic reading.

\section{The Image of London in William Blake's London as Accusative Weapon against the Brutalities of English Realities}

\subsection{The Accusation against the Social Oppression of English Society through the Poetic Images in London}

In the view of the correlation between the poetic image and the visualized manifestation of social realities in the pictorial presentations of poetic text, it can be indicated in the visual observations of a variety of poetic scholars in combination with the theoretical insights of visual arts that the poetic text is not just a carrier of poetic emotions that have been firmly rooted in the minds of a lot of poetic readers but also that of poetic narration that have been playing an important role in the thematic revelation and structural representation of the social realities in line with what they are going in an actual way, for it has been held in the studies of poetic scholars that what has been reflected or represented in a poem is a pa- 
noramic image of the society where a poem has been set in for the aim of giving an account of various social phenomenon of a society in accordance with the supported evidences that can be found out in the social lives of the citizens whom a poem is speaking for. In view of this relationship between what has been written in a poem and what has been reflected there, it ought to be noted that a poem is to an extent both a macrocosm and a microcosm of the actual lives of a society, for the epistemological and ideological typicality reflected in a poem has derived from the conceptual and perceptive generalization of a poem while he is dealing with the social problems that have been disturbing the internal minds of the citizens of a society, causing their emotional anxieties and even bringing about the universal chaos in the whole society.

From this point of view of this reflection of social phenomenon, it can be strongly felt that the very thoughts that have been put forward in a poem in an implicit way is the every sort of poetic echoes that can be found in the poetic traces of social development by recording every single moment and every single event at a given historical moment in a picturesque way after a careful categorization of them and an overall comparison of them to find out the typicality of the poetic images in a poem that have been closely associated with the social reality and have been giving a vivid account of them to make sure that the poetic images of a poem are the best epitomes of the social reality.

What seems to be similar to what has been stated above is that London, as one of the mightiest poems of William Blake, it has been characterized with this poetic typicality that can be manifested in the articulation of the internal voices of the citizens and revelation of the profound absurdities of the social realities of England which has been typified in everything pained in London where has been believed to be the heart of England for a long time in the eyes of almost every citizen around he world in that it has presented its poetic readers a panoramic and an overall picture of the exploitation and oppression of the social institutions that have been popularly implemented in the capitalist society in a scaring way based on the poetic images that have been portrayed in this poem to scan and denounce the sound bitterness buried in the social realities of England to justify the first minor proposition of this essay just as what to be analyzed below in line with what has been reflected in the first stanza of this poem.

Considering what has been visualized in this stanza, it can be indicated that an overall picture of the society that has been imprinted on the unavoidable and inerasable realities of English society has been found out in and composed of the poetic image of the internal perception of the narrator, the segregated image of the spatial demarcation, the poetic visualization of the street of London as well as the poetic image of the facial expressions of the citizens of London as to be dealt with below in four respects.

In the case of the poetic image of the internal perception of the narrator of this poem, it can be felt that what he cares most is the spirituality of the citizens who have been pictured in the image of him as what has been entailed in the 
word "wandered" in the first line of this stanza as an authentic responses the narrator has racked his brains to give to the cruel realities English citizens who have been typified by London citizens on account of the typicality of what has been going on in London for the aim of voicing the sound bitterness of the majority of English citizens in the advancement of industrial revolution and mechanical civilization that has been characterized with inhuman cruelty and indifference and showing his conscientious concern for their unbearable experiences, for it can be associated with the selection of this word that the citizens who have been represented by the narrator seem to be lost in spiritual blindness, homelessness, idleness as well as hopelessness. Compared with the promising society existing in the imaginations of ancient sociologist, humanists as well as philosophers, it can be evidently seen that the citizens who have been leading a good life will not be wandering through streets, for those who have been better-off will not be likely to give others the wandered impression that they have no quite place to locate their exhaustible bodies and anxious souls, those who have been in a possession of enough fortunes will not be likely to walk along the streets with aimlessness, those who have been occupied with their jobs will be unlikely to waste their time wandering through the streets; therefore, to this extent, what has been implied in this line is that the narrator intends to raise the attentions he wants to pay to the unemployment of the citizens who have been suffering from the unspeakable bitterness caused by the enclosure movement that has been depriving them of them homes and the exploitation of the employers who have been taking into their consideration nothing but the maximization of their commercial profits that have turned out to be based on the exploitation of the laborers who have no better choices but accept manual work as opposed to mental work owing to their inability to take mental work as the ruling class. In other words, they are unable to change their fates in view of their illiteracy that has made it possible that they are unable to see through the profitable motivation of their bosses who have been making big fortunes by exploiting the values of the citizens in the name of fair and free competitions as proposed in the institutional proclamations.

For the part of the segregated image of the spatial demarcation, what ought to be mentioned below is that the stereotyped demarcation of the geological spaces between the ruling and the ruled as manifested in the first two lines in the application of the word "chartered" so as to give a panoramic account of the social discrimination between the ruling classes and the ruled classes of English society as well as the hierarchical stratification and segregation of the permanent population of English society at that time, ought to be thought of as a poetic insinuation of the hegemonic and barbarous privatizations of the majority of shared resources of all the members of English society owing to the internal greed of the bourgeoisie who has been believed to be the spokesmen of the rich and the noble and extremely lost in the distorted values of mammonism, the hierarchical prejudices against and exclusions of the rules classes in the form of the possible ra- 
cial, cultural, epistemological as well as ideological discrimination, the spiritual repression and the cultural segregation that have, for a long time, been considered to be surprisingly abundant in the realities of English society and extremely reasonable in the minds of the ruling classes regardless of its cruel inhumanity based on the deprivation of what the ruled classes ought to have been given to, the legal protection of the ruled classes with regards to their continuous domination exemplified in their avaricious occupation of the major resources of the whole society in order to meet their avaricious needs of maximizing their own profits on the basis of minimizing those of the ruled classes at the cost of throwing the latter into the abysses of poverties, sterilities and fragilities, as well as the legal deprivation of the ruled classes in regard to their subjugation or subjection to the dominated authority in the possessions of social resources, cultural resources, technological resources as well as intellectual resources owing to the abnormal sense of political, social, religious commercial, academic, cultural, educational, medical, technical as much as intellectual sycophantism based on their blind beliefs in and despaired timidity of the authority of the ruled classes brought about by their political, social, religious commercial, academic, cultural, educational, medical, technical as much as intellectual poverty that have turned out to be likely to enable them to be lost in cultural stupidity, technological stupidity, educational stupidity as well as intellectual stupidity in relation to their unwillingness to make progress in those fields because of the cultural, technological, cultural, educational as well as intellectual manipulation of the ruled classes in the name of the epistemological promotion of the ruled classes under the sweetest excuses of concerning the ruled classes just as what has been dealt with in the values of an ancient Chinese philosopher named Mencius to the effect that those who are best at mental work are inclined to govern those who have done best in manual work.

To some extent, what the narrator has given a picture of in this time is an ingenuous articulation of the poetic image of the social realities of England at that time as is characterized with the image of cultural, technological, cultural, educational as well as intellectual cannibalism in the context of the overall developments of the industrial revolution based on enclosure movement, and the mechanical civilization that has been required to be achieved to speak for and make profits for the ruling classes in earlier bourgeois society.

With regards to the poetic visualization of the street of London in this poem, it can be indicated in the picture that have been given in the two echoes that have been given to the social injustice of English society just as what has been implied in the image of the "chartered street" in first line of the first stanza of this poem London, which on the one hand has implied the poetic readers that the street, as a shared space of the major population of this city has been occupied by and monopolized by the ruling class, for this is, in narrow sense, a textual echo that has been given to the monopolizing realities of London society and, in a broad sense, a textual insinuation of the social injustice of English so- 
ciety that has been brought about by the enclosure movement in the history of the development of capitalism concerning what the major population of English society has paid in the process of the capital accumulation based on their unspeakable pains, the rapid development of the industrial and mechanical civilizations of this society as well as the hegemonic occupation of the public spaces that ought to be shared between the ruling classes who have turned out to be in possession of the discursive rights of the entire society that have made them entitled to boss and bully the ruled classes at random in an impersonal way and the ruled classes who have been deprived of the very discursive rights that they ought to have enjoyed in their lives on a daily basis; on the other hand, it has alerted them that in addition to the exclusion of the public spaces of the city London as one of the public or social resources that has been likely to help them enrich their own lives in their spare time in the form of entertainments to get rid of the fatigues of their work for the young workers of the ruled classes or kill the boredoms of the retired workers who have been in need of living a peaceful life over the rest years of their lives, the ruled classes have also been deprived of their rights to share with the ruling classes the natural resources as has been symbolized in the water resources of the "Thames" which have been chartered by the bourgeoisies for the aim of protecting their own interests against any forms of damage in the name of law that has been made to protect the ruling classes and repress the ruled classes in any societies composed of the ruling classes and the ruled classes.

To put it in another way, the legislation is nothing but the representation of the ruled classes who have been manipulated for a long time owing to their own stupidity caused by their inadequate education they have received. The only way for the ruled class to change their lives is to fight against their bosses, that is, the ruling classes in order to subvert their ideological values and enjoy the discursive rights they ought to have enjoyed. At thought of the root reasons for the ideological poverty of the ruled classes of English society, what ought to be noted is that they have been unable to receive a good education that can be regarded as an effective way for them to stay away from their educational and intellectual poverty, for this education is, to some extent, a potential danger or threat for the maintenances of the rights and interests of the ruling classes who have, in a superficial sense, turned it into a noble or an elegant consumption that is only available for themselves rather than the ruled classes. In a profound sense, this ought to occur to the minds of the ruled classes that the noble consumption is a strategy the ruling classes have taken to protect themselves and manipulated their ruled classes in the field of ideological domination and the educational exploitation that have been depriving the ruled classes of their rights to receive a good education in the name of elitist education or optimal education just as what Alexander Pope has warned his poetic readers that a little learning is a dangerous thing.

With respect to the poetic image of the facial expressions of the citizens of London in this poem, it will firstly come to the minds of poetic readers that the 
ruled classes of English society has been suffering from sound pathos and pains at that stressful age in a symbolic way in line with the correlation between poetic characterization and social representation in the process of the textual construction of this poem which has been formed in the image of the cruel realities of English society over that historical period owing to the double stresses they have to be faced with while dealing with the internal exploitation and repression and the external destruction caused by French revolution.

So to speak, what has been going on at that historical moment has been clearly reflecting on the expression of London citizens who have been believed to stand for all citizens throughout English society who have been wandering in the streets when they are forced to embrace everything that has brought them endless unhappiness, hopelessness, loneliness, blindness, helplessness as well as homelessness, for they have turned out to be rootless outcasts who are unable to dwell on even a single place to tranquilize their exhaustible souls owing to the enclosure movement in the process of capitalist development. Therefore, what they can not but do is to wander in the streets aimlessly and joylessly on account of their jobless situation caused by the popularization of the machines that have been likely to produce far more products than the workers can not but do the manual work that make fewer profits for the factory because of their illiteracies in more than one respect just as what has been expected in the minds of the bourgeoisie who have been intentionally depriving those workers including women workers and infant workers of their opportunities to receive a good education in order to have a good control over them and make them to make more profits for their bosses who have been depending more on the machines instead of men to produce more products for them to make much more money. After all, at the age of mammonism, profit has been the only purpose of most bosses whose minds have been preoccupied with interests and profits rather than humanities. At this thought, it might occur to one that how foresighted or farsighted are those ancient Chinese thinkers and philosophers who have put forward the thought that commercialism ought to be prevented owing to its corruption effects on the personalities as well as the souls of human beings before the personalities and souls of Chinese business men are corrupted in an overall way.

As a matter of fact, the real vices of bourgeoisie in the development of capitalism lie in the fact that they have been racking their brains to exploit not only adult workers but also infant workers who should have read at schools if they had been endowed with the rights to receive a good education, who should have lived a carefree life if they had not been forced to work in the factory to make a living or win their breads, and who should have been enjoyed their childhood if they had better choices. However, they are unable to do so. They have to wear gloomy expressions as their fathers, mothers as well as their relatives who are even unable to take care of themselves, let alone their kids.

In this case, the poetic evidences that have carried the worries, anxieties as 
much as sorrows of the adult and infant workers can be found in the third and fourth lines of the first stanza of this poem as exemplified in the word "mark" that has been written on the faces of every worker in the street with a variety of unspeakable and unbearable pains hidden behind their expressions. What has to remind of the poetic readers of this poem in an emphatic way is that the transformation of the singular form of the word "mark" into its plural form "marks" has indicated that the gloomy bitterness of those workers has been characterized with an growing inclination of inevitable multiplications in pace with the horizontal and vertical developments of capitalism, the homonymous and homographic reiteration of the word "marks" seem to have been telling the poetic readers that the sins and vices of bourgeoisie appear to have fallen into an endless and vicious circulation and the workers are doomed to work out no solutions to those vicious problems unless they have been aware of learning something to run away from the bonds and shackles they have been wearing in both physical and spiritual worlds, and the transitions of the word "mark" from verb into nouns have also suggested that the harms that the ruled classes have been done to have been transformed from implicit pains into explicit ones owing to their becoming increasingly remarkable and noticeable day after day according to the poetic observation of the phenomenon of English society that has come to the poet's mind in a despaired way.

For the part of the poet, what he has respectively infused in the third line and fourth line of the first stanza of this poem is that he has been trying every means to give a vivid and an authentic presentation to and record of the intolerable cruelty of the bourgeoisie and show his great sympathy for the poor who have been turning out to be suffering sound bitterness in the depiction of their facial expressions that have been characterized with the marks of sadness and weakness that seem to be more painful than to be killed, for it is much more cruel for them to be marked on the face than to be killed in a few seconds in the form of a quick death because the mark here refers not only the physical pains but also spiritual tortures in regard to its symbolic implications of discriminations, dishonors or disgraces. It is for this reason that out comes the fatal hatred or hostility of all the poor citizens who have been viewed as the working class of English society against the capitalist class caused by the sharp contrast between them of in terms of their property gap. Therefore, it is clear enough that the poor live in a world of deprivation and suppression where the rich and the prestigious hold power and threaten them, and that the whole country seems to be a world where the poor have been mercilessly exploited, tortured, dwarfed, bullied and discriminated. Although they can rebel or resist against those social sins, vices and injustices, they are weak in that their weakness has been rooted in their instinctive consciousness just as what has been exemplified in their facial expressions.

From the perspective of reflectionism, it is better to say that the "marks" marked in their faces are the symbolic images of both the cruelty caused by social injustices and the weakness and sadness of the poor in accordance with the 
theoretical illumination that social forms are the reflections of the social existences in a given society, which ought to be true of English society based on the evidences that have cropped up in poetic realities that make distinctions from social realities, historical realities and psychological realities, for the poetic realities have been articulated in a ingenuous way that is not easy for the average readers to figure out on account of their poetic stupidities and superficialities. In this sense, it might be universally true that the poetic texts can serve as the best ways to give account of the social cruelties that have been torturing the poor from poor infants to poor adults and show the indignations of the poets that have been likely to be hidden in the poetic lines of the poetic texts as an outlet of the hostility of the poets. And this also applies to this poem London, for the poetic images of suppressions, exploitations, discriminations, as well as manipulations have been made best use of and regarded as strong critical weapons to show his accusations of the cruelties and brutalities of English societies by means of exposing to all the genuine realities of English society at that age in an artistic way that enables the poets to be exempt from the political or religious prosecutions in the form of the ideological censorships in the name of testing the political or religious correctness of all publications.

\subsection{The Accusation against the Class Repression of English Society through the Poetic Images in London}

As far as the correlation between poetic image and the responses it has given to the social reality that has been mirrored in the this poetic image, it ought to be aware that the relationship between them is a remarkable echo to the specific relationship of production like the relationship between the opposite classes of a given society in other words the ruling class and the ruled class of a society. In this regard, the class relationship is likely to become a focus of sociologists in most sociological studies in an evident way that has believed to give a picture of the superficiality of class struggle between the ruling class and the ruled class and to be easy for the average readers to perceive the superficial articulation of the problems in this respect, but hardly likely to be an emphasis of a poet who has been keeping in his mind his instinctive conscience in most of the poetic texts he has been producing in a profound fashion that takes a consummate poetic skills that have been composed of lexical skills, rhetorical skills like metaphors, hyperboles as well as antitheses, acoustic skills manifested in the rhymes, rhythms as well as metrical arrangements, semantic skills, pragmatic skills, as well as narrative skills that have been adopted familiarly and invisibly in a given poetic text to avoid the textual censorship of the authorities, to show his respect for love and life, and take care of the bitterness of the lower classes through the revelation of the harms the upper classes have done to the lower classes owing to their nearly total losses in possession of others' fortunes driven by their insatiable desire of possession and greed.

To find out in this poem titled London what has been dealt with above, it is necessary to make an explicit analysis of it according to the implicit permeation 
of the specific class consciousness of the poet into the textual configuration of this poem by taking the second stanza of it as an analytical sample of this essay to support the second minor proposition of this poem in order to make it reasonable to finish this logical justification that the poet of this poem William Blake has permeated into the textual textures of this poem to show his indignant accusations against the class repression of English society in his understanding of the class struggle between the ruling classes and the ruled classes of English society as a specific responses to the conflicts between the bourgeoisie and the proletariat in this capitalist society.

Considering the exploration of these textual evidences in this poem in relation to the class conflicts between the bourgeoisie and the proletariat, the textual analysis will first make its way to the limited freedom of the citizens including infants and adults who have been living in London, for the former hasn't been able to make a living at the beginning of their lives when they cannot but be thrown into the abysses of fears owing to the absence of the supports from their parents, the loves from their parents, the cares from their parents, let alone those from the mainstream society where the former has been depending heavily on the latter who have made great efforts to win their breads to support their families. However, they cannot do so, for their opportunities have been robbed of by the machines that have been dwarfing the former who have been depending on their manual work to make a living owing to the unfair facts that they have been deprived of the opportunities to develop their abilities, to edify their sentiments, to broaden their horizons, to highlight their wisdoms, and improve their skills and technologies just as what the society is in urgent need of. For this reason, the former have no choice but accepting the tragic reality of unemployment in spite of their passionate cries along the streets in the hope that they are likely to raise the extensive attentions of English society without knowing that the prospect of doing so is so slim that they are doomed to be starved to death with their infants.

Apart from the miserable responses of the infants and the adults, the lexical reiterations of the adjective "every" in this stanza in a homographic way has also been playing an important role in reminding the poetic readers of this poem that now that the new lives of this society haven't been valued in a universal way in spite of the numbness that has been felt at every corner of the society, the declines of the population of English society will be bound to be inevitable to the effects that the seemingly prosperous society will be doomed to be deteriorated and destroyed owing to the potential destruction that will become a reality in the near future, and that the society that has taken rare cares of the new lives is not a wonderland but a wasteland that has been filled with no promises that can be realized as long as the impossibility to abolish the "mind-forged manacles" continues to exist in the social realities of the entire country on account of the very darkness that English society has been characterized with for ages.

To the extent of the decreases of the population in English society, it might be considered to be reasonable that the deaths of the adult of English society at that 
time might make a great contribution to the development of the entire society, for the fewer are the adults, the more resources will be saved for the society in the context of the relative over-populations at that time without knowing that without the supports and cares of the adults, the old and the infants are unlikely to live and without the growths of the infants and the supports of the adults, the whole society will be doomed to go bankrupt with the extinctions of all the citizens in that society. Based on this, it can be inferred that the successive oppression of the bourgeoisie over the proletariat must give rise to the distinction of the latter and them to the former themselves because the former also have much dependence on the latter, for without the painstaking work of the latter, the former are unlikely to feed themselves owing to the emergent declines of necessities like foods that they have been produced by the latter suppose the latter are unable to resist against the former for good either in violence or in peace.

To be brief, the development of English society lies in the self-disciplines of the former by reducing their repressions of the latter to the least and taking into consider the bottom-lines of their violence or the breaking points of the latter who have been suffering from the manacles they have been wearing in their minds and souls, for those manacles are on the one hand likely to madden the latter and on the other hand the former as long as the latter have begun to realize the importance of their unified resistance against the former and their shared confrontation with the former. That is because even if the former has taken up $80 \%$ of the social properties while they have made up only $20 \%$ of the social populations. From the perspective of barbarism, the former will not be bound to defeat the latter imagine that they are not defeated. In that case, the authority and power in their hands might be taken over by the new owners if the latter have been endowed with the same educational opportunities to enlighten their intelligence. Although the latter haven't realized this danger, the poet of this poem William Blake has realized it in this poem as exemplified in his depictions of the fears of the infants, the cries of the adults, as well as the indignations of the latter out of the sympathy he has been showing for the underdogs of English society in that time. Suppose one of the latter has been enlightened from the real intention of the poet from his reading of this poem indebted from his rare ability to perceive the truth entailed in this poem, a series of chain resistances or rebellions against the former will come about one after another.

Based on those signs echoed from the depictions of the correlation between the bourgeoisie and the proletariat of English society in that historical period, it can be strongly felt that the confrontation between them has likely to make its way to its outbreak if there had been no epistemological manipulation of the latter by preventing them from becoming awake of their treacheries by means of sinking them into stupidities for ever or obtaining the possible opportunities so as to become aware of those treacheries after having receiving a good education. What the poet of this poem has done is to show his passionate accusations against the ruling classes of English society, to warn them of the possibility for 
them to face the music caused by their maltreatments of the ruled classes, and show this great concern for the ruled classes concerning their miserable experiences owing to the blind losses of the ruling classes in the endless satiation with their private desires of exploiting the ruled classes. However, for the sake of the peace of the whole society, he hasn't reminded the latter of their collective resistance against the former in a violent way to subvert the epistemological values the former have been implanting into their minds to reach the aim of ideological slaveries.

Therefore, what can be seen in this stanza is that the poet has been lost in the emotional and epistemological ambivalence, for on the one hand, he has been trying his best to disclose the vices and sins of English society by taking the poetic images in this poem as an accusative weapon to awaken the social conscience and ask the ruling classes to pay attention to the dangerous consequences of their amoral performances, and on the other hand, he feels the strong unwillingness to see the damages that are likely to be done to the ruled classes.

\subsection{The Accusation against the Religious Misconducts of English Society through the Poetic Images in London}

In responses to the theoretical insights regarding the relationship between religious beliefs and social realities as elaborated above, the religious maltreatments the ruled classes have been given can be explained from the perspective of reflectionism to the effects that religious malpractices are the correspondent reflections of religious corruptions that have been imprinted on the specific religious ugliness that has most to do with the interaction or combination of the dystopian zeitgeists of both industrial revolution and French revolution according to the reflective maxim that the religion of a given society as an indispensable components of the superstructure has been closely related to the economic bases of industrial revolution at that age grounded on the remarkable effects the latter has on the former in a determinable way and the latter on the former on the latter in terms of promotion and prevention just as what to be analyzed below in reference to the textual samples found in the third stanza of this poem London. To make an exploration of the correlation between religious echoes and the authentic records of the social realities of English society as what has been manifested in the children's cries and the soldiers' signs articulated in the third stanza of this poem London, what ought to be dealt with below will be expounded in terms of the confrontation of religious purification with religious pollution, the confrontation of the religious pacification with religious destruction exemplified in its collusion with governmental corruption respectively in the poetic construction of the images of London that have been composed of both religious degradation and governmental decadence owing to the profitable collisions between the religious hierarchy and the monarchy of English society that have turned out to worsen the lives of the ruled classes and stain the purity of religious clerks who ought to have transmitted into the minds of their believers the 
religious values that can be regarded as an approach to atone for their original sins despite of the possibility that the redemption of the original sins of the believes is likely to be regarded as a decorated excuses for the religious clerks to maximize their own profits that have been made in the name of the grace of God.

For one thing, the strong confrontation of religious purification with religious pollution has been articulated in the first two lines of the third stanza of this poem. A meticulous effort have been made to dig out the profundity of those lines, the poetic readers of this poem are likely to figure out the self-evident inconsistency and the apparent ambivalence between the religious doctrines and the religious conducts of the churches because of the governmental manipulation of the religious affairs of English society. In this sense, it can be inferred from the correlation between religious hierarchy and the monarchy that the former has to be forced to speak for the latter who is actually the epitomic representation of the ruling classes while the latter tends to have an absolute control over the former, and that what the former has been doing for is nobody but the latter and ruling classes to protect their interests against any losses because they have a lot in common with each other in this respect in spite of the occasional disagreement with each other and what the former has racking their brains to do for the aim of achieving the satisfaction of the latter is to stupefy the former by taking advantage of the religious transmissions in a legal sense to restrict the instinctive conducts of the former through treacherous deception and hypercritical proclamations. To be more evident, what the former has been doing is not purifying the souls of both the ruling classes and the ruled classes but polluting the souls of the ruling classes in the recognition, acceptance and transmission of mammonism and stupefying the minds of the ruled classes by all means including the exploitation of their opportunities to acquire their knowledge, to develop their wisdom, let alone criticize the unreasonable values they have been forced to receive and the enslaving education they have been offered. In other words, the religious clerks who have been expected to be the intellectual elites of the entire society have been manipulated by the monarch who have been flattered, beautified and even divined by the ruling classes to grant their own interests and make endless exploitation of the ruled classes who have been trying every means to assimilate rather than dissimilate them to the effect that the intellectual elites of that society have not been speaking for the ruled classes but speaking for power, authority and interest, which seems to be true of the reality of every society in the history of human beings.

For another thing, just as what has been referred to above, the introduction of the intellectual elites of an entire society who ought to have been working in the field of religious studies has been further strengthening the domination and consolidation of the ruled classes and sharpening the gap between the altruist intellectual elites and the utilitarian intellectual elites of that society, which has been typified in the increasing confrontation of the religious pacification with 
religious destruction as what has been implicitly elaborated in the first two lines of this poem in a dexterous way.

Therefore, instead of making great efforts to seek for the religious truths that are likely to enable the religious believers of both the ruling classes and the ruled classes to make their ways to their spiritual liberation, pacification, purification as well as salvation, the religious clerks have chosen to be hand and glove with the ruled classes and instigate them to do more and more harms to the ruled classes by means of coming up with more and more treacherous conspiracies for the ruling classes to put down, enslave and fool the ruled classes in the field of political domination, economic exploitation as well as educational and religious stupefactions regardless of the bitterness and sadness of the ruled classes as exemplified in the chimney-sweepers' cries and the soldiers' signs.

Out of question, what the religious clerks have been doing in line with what has been echoed in those two lines is polluting their own minds and souls as well as those of the ruling classes. In fact, the poetic diction of using the word "black'ning" to modify the word "church" that has served as the subject of this line and goes in agreement with the predicate "appalls" has suggested the poetic readers of this poem that everything related to the churches that has been serving as authority of the religious beliefs, truths and pursuits have been infamous throughout the country, for their minds have been seized with sheer the indifferences that have been typified in their turning a deaf ear and a blind eye to the religious violence of the country, the tragic experiences of the infants as well as the soldiers who are the biggest victims of English society in the historical context of industrial revolution and French revolution, which has been quickening the exploitative paces of the ruling classes and worsening the bitterness of the ruled classes. What the poet intends to tell the poetic readers of this poem in those lines of the third stanza of this poem is that it is the hopelessness and desperation that the whole society has been lack of owing to their indifference to the promising infants who have been symbolizing the rehabilitation of the whole country and the soldiers who have been rested too much on the triumph and victories on the battlefield.

One more analytical sample in this respect is the sharp contrast between the black of the church and the red of palace in that different as the colors of them are from each other, the effects those two different colors have on the minds of the poetic readers of this poem are the same if they have taken into account the symbolic implications of those colors implied in the cruel and brutal realities of English society, the sameness of them will be located in the tragic pathos the strong distance those two colors have been refracting or insinuating in an amazing way just as what has been implied in the word "appalls" in the second line of the third stanza of this poem as well as its same rhymes in the word "walls" in the last line of the same of stanza of this poem. Therefore, it can be noted that the difference in colors and the sameness in rhymes have been serving as important marks of the religious darkness of the society and the unbearable bloodiness 
of the war owing to the mutual relationship between them to the effect that the crueler the wars are, the greedier the ruled classes are. In this sense, the war has been offering those ruled classes to make big fortunes.

Of course, what ought to be mentioned most is that the blood that runs down in the place walls has transmitted a sad news to English citizens that the ruled classes have been likely to face their music in the wars, for the palace has always been the place where the safety of the head of a country has been granted due to its ingenuous defense to and preparation for the attacks of the enemies. In other words, it is undefeatable but the blood of the soldiers has been seen running down from the walls of the palace, which has given the poetic readers of this poem an important impression that the entire destruction of this country is around the corner in an inevitable way. It is this anticipated destruction that quickens the exploitation and suppression of the religious clerks and make it clear that the poetic readers of this poem have been enabled to give a picture of the religious ugliness of the religious clerks in terms of the stains that have turned out to be inerasable in the rotten or corrupted personalities of those religious clerks at the very crucial moment of the war based on their elimination of the mental bonds and chains given by religious beliefs in advance caused by their religious infidelity.

In brevity, it can be summarized from the analyses made of above that the poetic depiction of the religious phenomenon of English society at that time has impressed the poetic readers of this poem that the religious hierarchy has been hand and glove with the monarchy owing to their shared interests in protection the profits of the ruled classes, that the religious ugliness has been made evident in the religious infidelities of the religious clerks when the destruction of the war is inevitable, and the religious believers have turned out to be the biggest victims owing to their being deceived by the infidel religious clerks when they have been trapped into a firm persistence of religious fidelity which has been regarded as a way for the ideological manipulation or control the ruling classes have had over the ruled classes. All that have been concluded above has been articulated in the poetic images of this poem produced by William Blake in such an implicit way that average poetic readers have a lot of difficulty in perceiving it.

\subsection{The Accusation against the Liberal Exploitations of English Society through the Poetic Images in London}

Similar to what has been done above in the process of reaching the analytical aim of finding out the poet's accusation against the cruelty and brutality of the realities in English society at that historical moment in view of the application of the theoretical values of reflectionism into the analytical practices, the textual analyses of the fourth stanza of this poem ought to begin with a humanist consideration that is likely to be taken into the crucial issue of the liberation of humanity of the citizens in the entire society in order to provide the English citizens of that time with a variety of blind liberties that have been epitomized in the 
sexual liberation in accordance with the social and moral chaos caused by the extensive corruption of sexual commercialization, the innocent satisfaction of sexual desires as much as the total destruction of both physical health and spiritual well-being of English citizens with the puritan asceticism that has been based on the abstinent humanities, the moral humanities as much as the rational humanities in puritan values compared with the sexual carnalism or sexual hedonism that has been related to natural humanities one after another as to be analyzed below in three folds based on the poetic images portrayed in this poem.

Firstly, in view of the extensive corruption of sexual commercialization, it has been transparent that the rapid development of commercialism in correspondent of the swift expansion of capitalism that has been marked with the expansion of both the mechanical production and industrial revolution respectively in the process of capital accumulation, has to a great extent, alienated the mentality and morality of English citizens by enabling them to attach a great importance on the profits they are likely to make and liberating them in such a thorough way that they are likely to do everything to maximize their profits at the cost of doing damage to the morality they have been sticking to with regards to love and marriage in which the notion of man's marital fidelity and woman's marital chastity has been gradually neglected throughout the country day by day. It is the gradual neglect of both of them that instigates men and women to be eager to set them from traditional notions of sexual asceticism as restrained in puritan values in the blind way in the sense of sexuality, which seems to be filled with humanity owing to their sheer ignorance of the respective and correspondent differences that are necessarily existing between humanity and sexuality, between humanity and bestiality as much as between sexuality and bestiality before they have decided to commercialize sexuality in the streets.

In this context, the universal phenomenon of prostitution begins to turn up in the streets of London who has been serving as one of the microcosm of English society just as what has been reflected in this poem London that most women have stayed up till "midnight" in the streets as described in the first line of the last stanza of this poem in order to find even a single customer to make a living but owing to the negative influences of the war, most men have gone to the battlefield and sacrificed there.

Therefore, fewer men are likely to become their customers. The fewer are those customers, the harder they are likely to feel it to make a living at the risk of being infected with sexual diseases or even fatal diseases. That is why they have to wait for the customers' visits till midnight apart from the reason that midnight is the best time for them to do their business according to their experience. Of course, from the bottom of their hearts, they are unwilling to do so because they have been aware of the risks of being infected with fatal disease but they are forced to do so because of their unemployment in mechanical production and the greedy exploitation of the bourgeoisie in order to make a living or even support their babies whose eyes have been filled with eyes upon their first visits to 
this world and first sights of their mothers' bitterness despite their unconsciousness of this business and the spiritual pollution of their minds in the process of their growths. From the point of view of humanism, this is not the laments of those women but those of the society that have been robbing them of their opportunities to acquire the skills to make a living and the war that have robbed them of their men who are unable to win their bread and get away from the breadline.

However, compared with the shocking terror of disease mentioned above, what those women are really afraid is not the fatal fear of this disease that has been regarded to be likely to shorten their life spans but the shortage of customers whom they have been depending too much on to meet their needs of making a living, for they are unable to make a living and support their babies without the frequent participation of those customers. That is why the young harlot keep voicing their curses to the miserable society that has forced a variety of men to have been involved in war and to be unlikely to become their frequent customers. In actuality, this is not the real reason for their curses, the real reason for this is that had there no wars, they could have lived with their men and relied on their men to work and support their families and bring up their babies because it can meet both their physical needs and spiritual needs.

Secondly, in the light of the innocent satisfaction of sexual desires of the innocent men and women at that age, it ought to figure out that the moral tolerance of the sexual freedom most men and women have been acquired from sexual dislocation from the traditional asceticism as claimed in puritan values has to some extent been doing a lot of harms to the families around considering the rapid increases in the rate of divorce, the rate of celibacy, the rate of prostitution as well as the rate of sexual corruption because it seems to be inappropriate for them to have a good control over their physical needs, which is in a sense in need of either partial or full satisfaction in order to make them cope with all the pressures they have been faced with in their lives.

On all accounts, the sudden liberation of men and women by giving them sexual liberties have been likely to throw them into a blind satisfaction of their sexual desires in their sexual indulgences, which has been believed to be the origin of their infection with a variety of fatal diseases or in other words noble diseases they are unable to cure. What is worse is that even if they are able to afford their treatments of their diseases, it is impossible for them to do so, for their fatal diseases have turned out to be incurable. What is worst of all is that their impulsive and temporal indulgences in the satisfaction of their instinctive sexual desires have destroyed their loves, marriages and families in a thorough way because of the heritable infection of their diseases to the effect that their children are likely to suffer from those diseases generation after generation. For the sake of preventing the continuous infection of their diseases with more of their generations, their children have to choose to be celibate throughout their lives, which means the racial or national extinction for the part of the country. Cer- 
tainly, the country dominated by the ruling classes that have been composed of numerous bourgeoisie ought to take charge of this extinction due to their exploitation of the educational liberties of the men and women from the ruled classes in addition to the spiritual distortion or degradation of the ruled classes who have been lost in their sexual satiation based on their beliefs in the sexual carnalism or sexual hedonism.

Therefore, what can be illuminated from the poetic images reflected in the depiction of the realities in the last stanza of this poem produced by William Blake is that something must be done to prevent the sexual carnalism or sexual hedonism from extensive transmission, for it pays too much to accept, perform and prevent it with its destruction taken into account.

Thirdly, as to the total destruction of both the physical health and the spiritual well-beings of English citizens instigated by the sexual carnalism or sexual hedonism, it ought to be admitted that the ruling classes of English society at that time have monopolized the medical services of the entire society to the effect that the opportunities for the ruled classes to receive the medical treatments of their fatal diseases caused by their innocent promiscuities have been exploited by the ruling classes who have taken up almost all medical resources of the entire society owing to the riches they have possessed just as what has been exemplified in the last line of the last stanza of this poem London.

In this case, men and women from the ruled classes of English society have nothing to do but suffer from the pains and sorrows caused by those diseases owing to their surprising poverty epitomized in their economic poverty, educational poverty, intellectual poverty, cultural poverty, epistemological poverty, medical poverty, etc. What they ought to pay attention to is that their poverty in those respects have made them rub shoulders with good medical services, let alone the medical treatments of their fatal diseases like venereal diseases and AIDS, for those diseases are to the disadvantages of both their physical health and spiritual well-beings as those diseases are likely to throw them into depressions, glooms, anxieties as well as other psychological diseases.

In line with the last line of the last stanza of this poem, what is more terrible is that their fatal diseases like venereal diseases have been passing down to their new babies who should have been believed to stand for their futures, to realize the dreams they have been able to, to stir a great sensation they have never expected before, and bring everything they have never heard of all over their lives. However, their heritable infection of their babies has spoiled everything dreamed of above owing to their worsening health and well-being. All in all, the poetic images depicted in this stanza have been telling the bitter stories of the ruled classes who have been represented by the typical sex workers at that historical moments, and regarded as one of the ways the poet of this poem used to accuse the cruelty of English society in terms of the liberal exploitation the ruling classes have been making of the ruled classes.

To sum up, it has been indicated in the analyses made of above that the poetic 
images of this poem has been thought of as an accusative weapon of the poet William Blake to show his indignation against the brutality and cruelty of English society over French revolution and industrial revolution with the theoretical enlightenment of reflectionism in regard to the social oppression, class repression, religious malpractices as well as liberal exploitation in that historical period of English society.

\section{Conclusions}

On the basis of the four feasible textual analyses of this poem London in terms of the respective accusations against the social oppression, class repression, religious misconducts and liberal exploitation of the cruel inhumanity and brutality of English society at that time through the poetic images in London with the theoretical supports of reflectionism just as what has been discussed above in details, it can be summarized from the support of the respective justifications based on those analyses that the major academic proposition of this essay is feasible in that it has turned out to be sensible to take the poetic images of London in William Blake's poem titled London as one of the accusative weapons for the poet to fight against the social cruelties and brutalities of English society typified in London for the part of the sound bitterness the proletariat have been suffering in their lives in the light of the social oppression, the class repression, the religious misbehavior as well as the liberal exploitation that has been extensively existing in almost every corner of the lives of the ruling classes of English society in the historical context of industrial revolution and French revolution, to show his profound sympathy for the ruled classes who have been suffering from unbearable pains and bitterness in their lives caused by helpless unemployment, fatal hungers, disgraceful diseases as well as social injustices with the theoretical and textual supports of the logical justification of the four minor academic propositions in the fourth part of this essay owing to the organic combination of the textual information carried in this poem with the theoretical inspiration of reflectionism in the forms of comparison, exemplification, elaboration and inferences in a respective fashion, and transmit his social consciences to his poetic readers in the hope that intellectual elites ought to take pride in seeking for the very truths that can speak for the interests of all citizens instead of searching for the vanity of the so-called disgraces begged from the ruling classes at the cost of losing their worthwhile dignities and initial consciences by the virtue of showing their intellectual sycophantism for the ruling classes rather than their academic altruism for the ruled classes.

For the part of the implications of the logical justification of this essay, firstly, it can be made evident in the minds of poetic critics that the profundity of a textual analysis lies in the dedication of the textual spaces to the profound analysis of poetic text that a poetic critic has been willing to devote the textual spaces of a essay or a monograph to his analysis of a single poem rather than that to his interpretation of many poems in a single essay; secondly, it is good for the poetic 
scholars to realize that the highest values of a poem lies in its implicit transmission of the social conscience that have been devoid of in the minds of most intellectual elites of the society for the aim of embracing and promoting social justices through the permeation of the profound intellectual conscience into their studies; thirdly, it is likely to come to the minds of the poetic readers that the real perception of the truth conveyed in a poem lies not just in the understanding of the structural beauty, lexical feasibility, linguistic profundity, cultural diversity as well as historical reality of it, but also the enhancement of the epistemological profundity that has been closely and crucially associated with the social, intellectual, academic educational, religious, and medical conscience of the poet who has produced it. And the application of the poetic images of London in William Blake's London as one of the ideological weapons to fight against the cruelties and brutalities of English society can be counted a good example in this respect for the poetic readers to make their ways to their poetic reading and poetic production in the future.

In spite of the discussion of the ingenuous application of the poetic images of London into the revelation of the social vices and sins of English society, the interpretation of this poem might be reduced to the ideological limitation that seems to be a little bit superficial owing to the limited academic resources that are likely to throw light on the logical justification of the academic proposition of this essay in a more reasonable and logical way, the limited academic horizons of the author of this essay as well as the relatively inadequate academic communication with international scholars in having a better understanding of their criticism of this poem. Therefore, an honest academic tolerance will be honestly expected of those dedicated scholars who might have been carelessly and purposelessly offended by this study.

To achieve academic breakthroughs in this regard, it ought to be necessary for the author of this essay to have a better understanding of this poem, the theoretical insights of reflectionism as well as the critical achievements of international scholars who have been devoting most of their precious time and energy to the studies of this poem.

\section{References}

Almasalmeh, B. (2014). A Deconstructive Reading of W.B. Yeats's Sailing to Byzantium and William Blake's London. Damascus University Journal, 30, 95-108.

An, R., Zhao, S. Y., \& Liu, W. Y. (2014). William Blake's Poetry: An Exploration of the Feasibility towards Spatial Dimensions. The Boarder Economy and Culture, 123, 90-91.

Bloom, H. (1987). Introduction to William Blake's Songs of Innocence and of Experience (pp. 1-28). New York: Chelsea House.

Brooke, S. A. (1920). The French Revolution and the Poets Who Preceded It, in His Naturalism in English Poetry, E. P. Dutton \& Company, pp. 69-91.

Chen, X. L. (2004). Is London Heaven or Hell? A Comparative Study of between William Blake's London and William Wordsworth's London. Journal of Huangshi Educational College, 21, 54-57. 
Eagleton, T. (2002). Marxism and Literary Criticism (pp. 46-49). Landon \& New York: Routledge.

Gilchrist, A. (1880). Life of William Blake (2nd Edition, pp. 116-119). London: Macmillan.

Guo, X. Q. (2014). A Comparison of the Poetic Presentation to London between William Blake London and William Wordsworth. Journal of Suzhou University, No. 2, 67-69.

Li, H. Y. (2007). The Outcries in the Darkness: An Interpretation of William Blake's London. Masterpieces Review, No. 7, 98-100.

Li, Z. X., \& Ma, Y. Y. (2017). A Rhythmic Analysis of William Blake's London. Journal of Jiamusi Vocational Institute, No. 8, 48-49.

Lukács, G. (1971). History and Class Consciousness: Studies in Marxist Dialectics (pp. 46-47). London: The Merlin Press Limited (trans. by Rodney Livingstone).

Naya, P. K. (2014). William Blake's London as a Surveillance Poem. The Explicator, 72, 328-332.

Pan, Y. W. (2001). A Comparison between William Blake's London and William Wordsworth's London. Journal of Huzhou Teachers College, No. 12, 194-196.

Price, M. (1969). The Vision of Innocence. In M. D. Paley (Ed.), Twentieth Century Interpretations of Songs of Innocence and of Experience: A Collection of Critical Essays (pp. 36-48). Englewood Cliffs, NJ: Prentice-Hall.

Qiu, L. Y. (2003). A Mirror to Reveal the Social Ugliness of Bourgeois Society: William Blake's London and William Wordsworth's London. Journal of Jiaxing College, No. 4, 127.

Sayers, J., \& Monin, N. (2012). Blake's “London”: Dialectical Reading and Poetic Place in Organizational Theorizing. Cultural and Organization, 18, 1-13. https://doi.org/10.1080/14759551.2011.631342

Selden, R. (2003). The Theory of Criticism: From Plato to Present (pp. 53-54). Beijing: Beijing University Press (trans. by Liu, X. Y., Cheng, Y. G., et al.).

Sun, A. L. (1999). The Most Powerful Poem: William Blake’s London. Jiangsu Foreign Language Teaching and Research, No. 2, 87-88.

Wang, L. (2009). An Analysis of the Employment of the Poetic Image in the Poetry of William Blake: London as an Example. Anhui Literature, No. 7, 91.

Wang, S. L. (1992). William Blake's London and William Wordsworth's London. Songliao Journal, No. 4, 106-109.

Wang, X. Q., \& Zhao, Z. G. (2008). An Initial Exploration of the Application of Symbolism in William Blake's Poetry. Writer Magazine, No. 14, 91.

Wang, Y. Y. (2013). An Exploration of William Blake's London. Journal of Changchun University of Science and Technology, No. 1, 86-87.

Wu, Y. (2015). A Stylistic Analysis of William Blake's London. Journal of Chongqing Three Gorges University, No. 1, 128-130.

Xie, N. (2010). An Analysis of the Organizational Function of Literary Field: William Blake's London as an Example. Northern Literature, No. 9, 23-25.

Yue, H. (2013). A Brief Analysis of the Spatial Form of William Blake's London. The Science Education Article Collects, No. 11, 53-54.

Zeng, F. R. (2005). The Ethic Thoughts in William Blake's Poetry. Foreign Literature Studies, No. 6, 20-21.

Zengin, M. (2014). William Blake's London: A Resistance to Power and Authority, Anka- 
ra Üniversitesi Dil ve Tarih-Coğrafya Fakültesi Dergisi, 54, 117-148. https://doi.org/10.1501/Dtcfder_0000001376

Zhan, C. J. (2013). William Blake and His Poem London. Theory and Practice in Language Studies, 3, 1610-1614. https://doi.org/10.4304/tpls.3.9.1610-1614

Zhu, G. (2006). Twentieth Century Western Literary Theories (p. 89). Beijing: Beijing University Press. 